\title{
THE ROLE OF PLATELET-RICH FIBRIN FACILITATES THE HEALING OF GASTROCNEMIUS MUSCLE DEFECT: A PRELIMINARY STUDY ON ANIMAL MODEL
}

\author{
Dwikora Novembri Utomo $^{1^{*}}$, Kukuh Dwiputra Hernugrahanto ${ }^{2}$ \\ ${ }^{1}$ Senior Consultant of Orthopaedic and Traumatology Department, Faculty of Medicine, \\ Universitas Airlangga, Dr Soetomo General Hospital, Surabaya \\ ${ }^{2}$ Resident of Orthopaedic and Traumatology Department, Faculty of Medicine, Universitas \\ Airlangga, Dr Soetomo General Hospital, Surabaya \\ *Corresponding Author: Dwikora Novembri Utomo, Senior Consultant of Orthopedic and \\ Traumatology Department, Faculty of Medicine, Universitas Airlangga, J1. Mayjen Prof. Dr. \\ Moestopo 6-8, Surabaya \\ E-mail: dwikora_utomo@yahoo.com
}

\begin{abstract}
ABSTRAK
Latar Belakang: Pembentukan jaringan parut sebagai hasil akhir penyembuhan otot yang cedera adalah masalah klasik yang belum mendapatkan solusi yang memuaskan. Jaringan parut ini akan menurunkan fungsi dan kapasitas fungsional otot. Banyak usaha yang sudah dilakukan termasuk pemberian platelet-rich plasma (PRP)namun sayangnya PRP ini memiliki keterbatasan seperti resiko reaksi imunologis, persiapan yang rumit, dan ketiadaan sifat sebagai scaffold. Platelet-rich fibrin (PRF) sebagai generasi baru dari konsentrat platelet adalah sumber faktor pertumbuhan dan memiliki keuntungan seperti bentuk gel yang menyerupai scaffold.
\end{abstract}

Tujuan:Mengetahui efek PRF pada penyembuhan cedera otot pada model hewan coba.

Metode:Penelitian ini sudah disetujui olek Komisi Etik Penelitian Fakultas Kedokteran Hewan Universitas Airlangga. Sebanya dua puluh kelinci New Zealand White Rabbitdibagi menjadi dua kelompok yaiu kelompok kontrol dan kelompok yang mendapat PRF. Pada kelompok kontrol, defek otot tidak diberikan apa-apa sedangkan pada kelompok perlakuan defek otot diberikan PRF. Kedua kelompok dievaluasi setelah minggu kedua dan keempat secara imunohistokimia untuk membandingkan ekspresi protein Pax7.

Hasil: Kelompok perlakuan yang mendapat PRF memberikan skor ekspresi Pax7 yang lebh tinggi dibandingkan kelompok kontrol baik pada minggu kedua maupun keempat.

Kesimpulan: Pemberian PRF memberikan keuntungan pada proses peneyembuhan otot. Hasil studi pendahuluan ini dapat digunakan sebagai landasan untuk penelitian menggunakan PRF selanjutnya.

Kata kunci: cedera otot, penyembuhan otot, platelet-rich fibrin

\begin{abstract}
Background: Scar formation has been a classical issue in the healing of skeletal muscle defect which will results in decrease of strength and function. Platelet-rich plasma (PRP) has been studied to enhance the healing of muscle defect. The disadvantages of it include the risk of immunologic reaction, time-consuming preparation, and lack of scaffold element. Plateletrich fibrin (PRF) is a new generation of platelet concentrate that provides good source of growth factors and scaffold element necessary for the healing. This study is to provide a fondation of PRF preparation and implantation for the healing of experimental defect of gastrocnemius muscle in an animal model.
\end{abstract}

Purpose: The goal is to provide a fondation of PRF preparation and implantation for the healing of experimental defect of gastrocnemius muscle in an animal model. 
Methods: Animal Care and Use Committee, Airlangga University approved the study. Twenty New Zealand white rabbits were divided into two groups. In control group, a defect was created in the right gastrocnemius and no implantation was done. In study group, similar defect was created with implantation of PRF. Two and four weeks after surgery, the defect was examined immunohistochemically for the expression of $\operatorname{Pax} 7$ protein.

Results: The implanted group showed higher IRS score in two and four weeks compared to the control group.

Conclusion: The use of PRF facilitates the healing of muscle injury. This study will be used as a fondation for further study on PRF.

Keywords:muscle defect,muscle healing, platelet-rich fibrin

\section{PENDAHULUAN}

Cedera otot adalah cedera yang sering terjadi saat melakukan aktivitas olahraga. Insidensi cedera otot pada olahragawan profesional mencapai 23 sampai 46 persen dari semua cedera olahraga. ${ }^{1}$ Insidensi cedera otot yang tinggi ini menyebabkan kerugian baik dari segi finansial maupun performa atlet. Data dari liga hoki es profesional National Hockey League Amerika Serikat tahun 2014 menyebutkan bahwa cedera otot terjadi pada $50,9 \%$ atlet hoki es sehingga menyebabkan setidaknya para atlet kehilangan kesempatan bermain setidaknya satu pertandingan dan kerugian finansial mencapai 218 juta dollar dalam setahun. Implikasi finansial yang lebih besar hingga 1,4 milyar dollar harus ditanggung oleh liga Major League Baseball akibat cedera otot pada atlet baseball. $^{2}$

\begin{tabular}{llr}
\multicolumn{1}{c}{ Otot yang cedera akan } \\
mengalami rangkaian proses \\
penyembuhan yang meliputi fase \\
inflamasi, proliferasi dan remodeling.
\end{tabular}

Proses penyembuhan otot ini melibatkan peran dan kerjasama antara sel punca otot dan faktor pertumbuhan. Sayangnya, jaringan yang terbentuk sebagai hasil akhir penyembuhan cedera otot bukanlah jaringan otot seperti sedia kala melainkan jaringan parut. Jaringan parut ini terdiri dari jaringan ikat yang berbeda dari jaringan otot asli sehingga menyebabkan berkurangnya kapasitas kontraktilitas dan fungsional otot setelah cedera. $^{3}$ Serabut otot baru yang terbentuk juga tidak cukup cepat karena proses penyembuhan yang lama, dengan rentang waktu penyembuhan antara 6 minggu hingga 6 bulan tergantung dari derajat cedera. Penyembuhan yang lama ini memiliki implikasi terhadap lamanya waktu return-to-play sehingga memberikan kerugian bagi atlet. ${ }^{4}$

Penanganan cedera otot yang ada saat ini bergantung pada derajat cedera otot yang terjadi. Sebagian besar cedera otot akut adalah robekan sebagian dimana cedera jenis ini umumnya bisa 


\section{Artikel Penelitian}

Vol 7 No. 1, April 2018

ISSN 2460-8742

http://journal.unair.ac.id/ORTHO@journal-orthopaedi-and-traumatology-surabaya-media-104.html

diterapi dengan baik dengan rest, ice, compression dan elevation atau yang biasa disingkat RICE dan obat-obatan antiinflamasi nonsteoridal yang diberikan dalam minggu pertama diikuti dengan fisioterapi progresif. ${ }^{5}$ Tindakan operatif dilakukan pada cedera otot dengan robekan total (derajat 3). Tindakan operatif dengan penjahitan robekan total dilakukan untuk mencegah komplikasi dini dan lanjut yang dapat terjadi. Namun sayangnya, terapi yang ada saat ini belum bisa memberikan hasil yang memuaskan seperti kondisi sebelum cedera terutama untuk atlet dengan aktivitas tinggi. ${ }^{6}$

Telah diketahui bahwa faktor pertumbuhan berperan penting dalam penyembuhan otot. Faktor pertumbuhan ini meliputi Fibroblast Growth Factos (FGF-2), Insulin-like Growth Factor (IGF-1), Vascular Endothelial Growth Factor (VEGF), dan Platelet-derived Growth Factor (PDGF). Studi oleh Hammond et al menyatakan bahwa pemberian faktor pertumbuhan dapat mengakselerasi dan meningkatkan kualitas hasil akhir proses penyembuhan otot $^{7}$. Pada studi itu, faktor pertumbuhan didapatkan dari pemberian autologous platelet-rich plasma (PRP).

Sebelumnya, telah banyak penelitian yang mempelajari efek pemberian PRP pada penyembuhan tulang, tulang rawan, tendon dan ligamen. Sayangnya, terdapat beberapa kekurangan yang dimiliki oleh PRP. Pertama, proses pembuatan PRP membutuhkan tambahan antikoagulan dalam jumlah banyak dan juga bovinederived thrombin yang berfungsi untuk mengkonversi fibrinogen menjadi fibrin. Tambahan thrombin dari bovine ini membuat PRP tidak murni autologous sehingga didapatkan efek samping berupa pembentukan antibodi terhadap faktor V,XI dan thrombin yang berujung pada koagulopati. ${ }^{8}$ Kedua, bentuk sediaan PRP yang berupa plasma yang cair membutuhkan bahan lain sebagai media pembawa atau penahan in-situ pada lokasi aplikasi pada otot agar PRP tetap berada pada lokasi cedera sesuai yang diinjeksikan dan tidak menyebar ke sekitar lokasi aplikasi yang diinginkan. Bahan yang sering digunakan adalah fibrin glue. ${ }^{9}$

Dari keterbatasan PRP tersebut, Platelet-rich Fibrin (PRF) mulai diperkenalkan sebagai generasi kedua dari PRP. Pembuatan PRF membutuhkan proses yang lebih sederhana, tanpa antikoagulan dan tidak membutuhkan tambahan bovine-derived thrombin sehingga PRF tetap terjaga sifat autologous-nya serta 


\section{Artikel Penelitian}

Vol 7 No. 1, April 2018

ISSN 2460-8742

http://journal.unair.ac.id/ORTHO@journal-orthopaedi-and-traumatology-surabaya-media-104.html

menghilangkan resiko terjadinya

koagulopati. Perbedaan proses

pembuatan menghasilkan bentuk yang lebih menyerupai gel pada PRF dibandingkan PRP. Bentuk gel ini diharapkan mampu berperan sebagai scaffold sehingga memudahkan untuk diaplikasikan pada cedera otot. ${ }^{10}$

Pada proses penyembuhan otot, peran sel satelit (satellite cells) sangat penting. Sel satelit ini yang akan berproliferasi dan berdiferensiasi sebagai sel prekursor jaringan otot. Dalam proses miogenesis, sel satelit akan mengekspresikan beberapa protein yaitu protein $\operatorname{Pax} 7$ selama proses multiplikasi dan protein $M y o D$ selama proses diferensiasi menjadi sel mioblas.

Penelitian ini bertujuan untuk mengetahui bagaimana efek pemberian PRF pada penyembuhan otot yang cedera. Penelitian ini akan mengevaluasi secara imunohistokimia proses penyembuhan otot yang terjadi. Hasil yang didapatkan dari penelitian ini diharapkan dapat dijadikan sebagai pertimbangan untuk menggunakan PRF secara klinis pada kasus cedera otot.

\section{METODOLOGI PENELITIAN}

Penelitian ini menggunakan tungkai belakang sebelah kanan dari dua puluh kelinci jantan New Zealand White
Rabbit (berat 2000 gram \pm 500 gram) dan telah disetujui oleh Komisi Etik Penelitian Fakultas Kedokteran Hewan Universitas Airlangga (nomor sertifikat: 682-KE). Kelinci secara random akan dibagi menjadi kelompok kontrol dan kelompok perlakukan.

\section{Persiapan PRF}

Darah vena diambil sekitar $5 \mathrm{ml}$ dari telinga kelinci dan dimasukkan ke dalam tabung vakum steril berukuran 6 ml tanpa tambahan antikoagulan (Gambar 1a). Tabung dilakukan sentrifugasi pada mesin sentrifugal dengan kecepatan 2700 putaran per menit selama 12 menit. ${ }^{11}$ Setelah proses sentrifugasi, akan didapatkan tiga lapisan yang terbentuk pada tabung (Gambar 1b). Lapisan terbawah mengandung sel darah merah dan lapisan teratas mengandung plasma selular. Di antara kedua lapisan tersebut terdapat gumpalan fibrin. Lapisan di tengah ini diambil $2 \mathrm{~mm}$ di bawah garis pembagi terbawah setelah terlebih dahulu membuang lapisan teratas (Gambar 1c).

Prosedur Pembuatan Model Cedera Otot Gastrocnemius dan Implantasi PRF

Kelinci dibius menggunakan ketamine $(40 \mathrm{mg} / \mathrm{kg})$ dan xylazine (5 $\mathrm{mg} / \mathrm{kg}$ ) secara intramuskular lalu 
Artikel Penelitian

Vol 7 No. 1, April 2018

ISSN 2460-8742

http://journal.unair.ac.id/ORTHO@journal-orthopaedi-and-traumatology-surabaya-media-104.html

diposisikan tengkurap. Dilakukan

desinfeksi menggunakan povidone

iodine $10 \%$ pada sisi posterior kedua tungkai belakang kelinci. Tempat inisi aalah $1 \mathrm{~cm}$ proksimal dari tendomusculo junction otot gastrocnemius. Insisi dilakukan pada kulit dan diperdalam hingga mencapai otot. Pada muscle belly otot gastrocnemius dilakukan eksisi otot dengan panjang $1 \mathrm{~cm}$, lebar $0,5 \mathrm{~cm}$ dan kedalaman $0,5 \mathrm{~cm}$ sehingga didatapkan model cedera berupa defek (gap) (Gambar 1d). Sebagai penanda, diberikan simpul menggunakan benang nonabsorbable pada jarak $5 \mathrm{~mm}$ di proksimal dan distal dari lokasi eksisi untuk memudahkan identifikasi saat pengambilan sampel nanti.

Pada kelompok kontrol, defek hanya dilakukan irigasi menggunakan cairan saline. Pada kelompok perlakuan, defek yang dibuat diisi dengan PRF yang sudah dipersiapkan (Gambar 1e).
Defek yang ada tidak dilakukan aproksimasi. Fasia dijahit menggunakan benang absorbable dan kulit dijahit menggunakan benang nonabsorbable. Semua kelinci dirawat dalam kandang terpisah di laboratorium hewan Intitute of Tropical Disease, Airlangga University dan diberi makan sesuai standar perawatan hewan laboratorium dengan pengawasan oleh dokter hewan. Sepuluh kelinci (lima kelinci dari masing-masing kelompok kontrol dan kelompok perlakuan) dibunuh dan diambil sampelnya setelah minggu kedua dan sepuluh kelinci sisanya dilakukan pada minggu keempat. Sampel diambil dan difiksasi menggunakan formaldehid $4 \%$ dan dipersiapkan dalam sediaan parafin blok (ketebalan $5 \mu \mathrm{m}$ ). Sediaan lalu diwarnai menggunakan antibodi Pax7 untuk dilakukan evaluasi imunohistokimia.

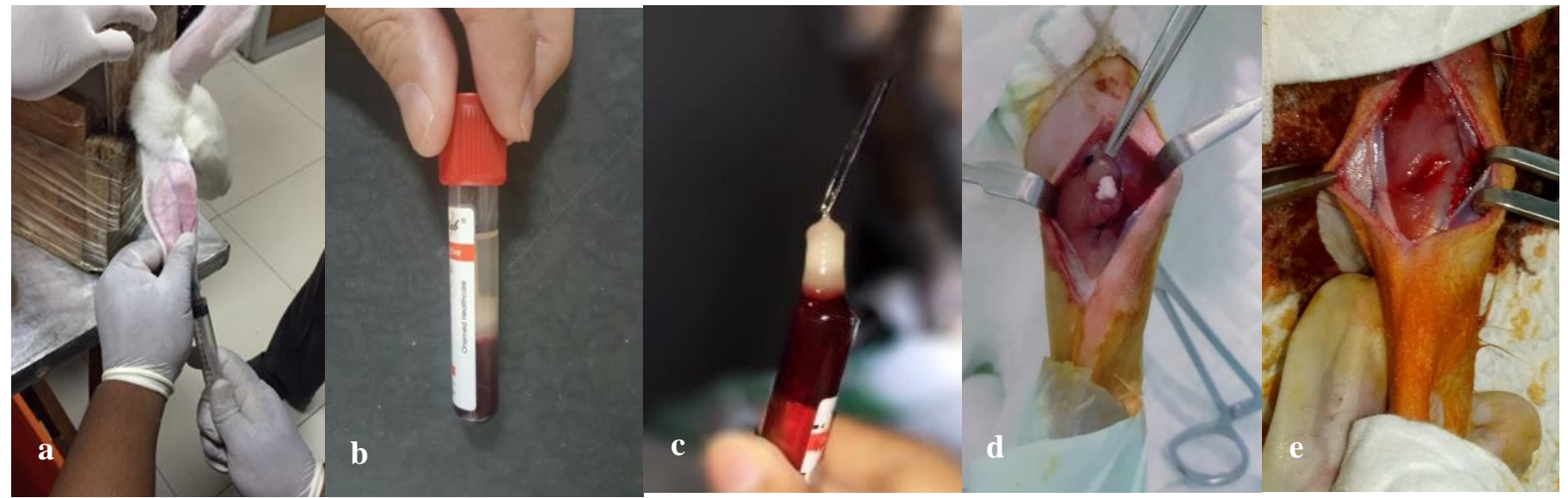


Gambar 1. Persiapan PRF dan model cedera. (a) Darah vena diambil dari telinga kelinci sebanyak $5 \mathrm{ml}$; (b) Setelah sentrifugasi, didapatkan tiga lapisan pada tabung. Lapisan tengah merupakan gumpalan fibrin; (c) PRF yang terbentuk dari lapisan tengah yang diambil; (d)

Model cedera berupa defek pada otot gastrocnemius; (e) Defek pada model cedera otot gastrocnemius diisi dengan PRF

\section{Evaluasi Imunohistokimia}

Setelah diwarnai oleh antibodi Pax7, evaluasi dilakukan dengan menggunakan mikroskop cahaya merk Nikon H600L yang dilengkapi kamera digital DS Fi2 300 megapiksel dan software gambar Nikon Image System. Ekspresi $\operatorname{Pax} 7$ dinilai dari sel satelit yang menunjukkan reaksi positif terhadap antibodi Pax7 anti-rabbit. Jumlah sel satelit per area fiber/serat otot dinyatakan positif bila sitosol berwarna cokelat (Gambar 2a dan b). 12,13
Data skor ekspresi Pax7 diperoleh menurut metode Remmel yang sudah dimodifikasi, dimana Indeks Skala Remmele (Immuno Reactive Score atau IRS) merupakan hasil perkalian antara skor persentase sel imunoreaktif dengan skor intensitas warna pada sel imunoreaktif. Seperti yang ditunjukkan pada Tabel 1. Data setiap sampel merupakan nilai rata-rata IRS yang teramati pada 5 (lima) lapang pandang (LP) pada pembesaran 1000 kali. $^{14}$

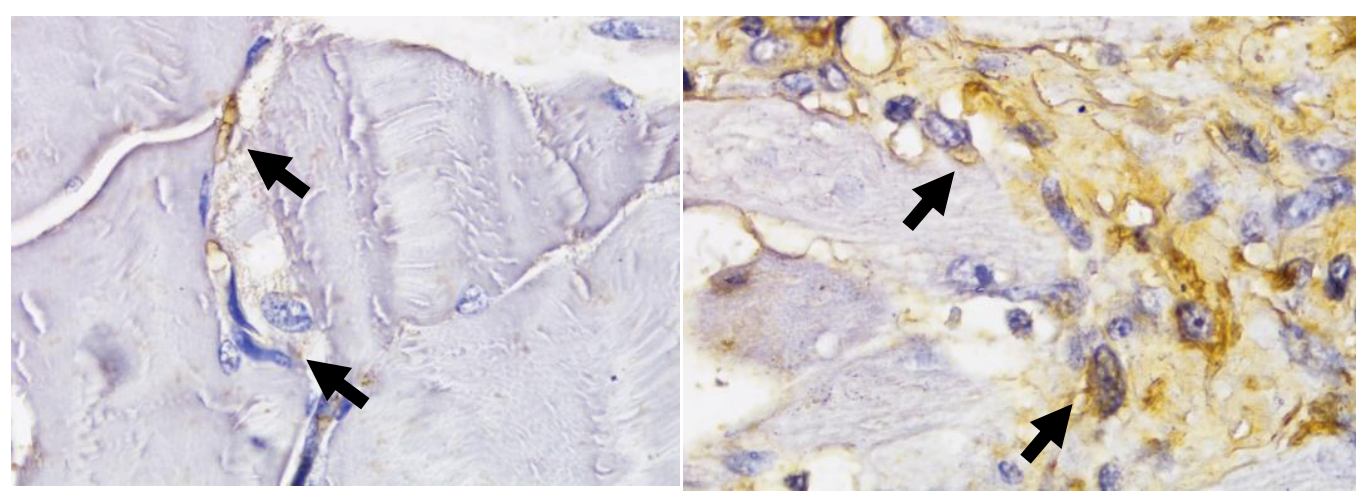

Gambar 2. Ekspresi positif dari Pax7 pada sel satelit berupa sitosol yang berwarna coklat pada pengamatan mikroskop cahaya

Tabel 1. Skala semikuantitatif IRS merupakan hasil perkalian antara skor persentase sel positif (A) dengan skor intensitas reaksi warna $(\mathrm{B}) \mathrm{IRS}=(\mathrm{A} \times \mathrm{B})$

\begin{tabular}{|l|c|}
\hline A & B \\
\hline
\end{tabular}


Artikel Penelitian

Vol 7 No. 1, April 2018

ISSN 2460-8742

http://journal.unair.ac.id/ORTHO@journal-orthopaedi-and-traumatology-surabaya-media-104.html

\begin{tabular}{|l|l|}
\hline Skor $0:$ tidak ada sel positif & Skor $0:$ tidak ada reaksi warna \\
\hline Skor $1:$ Sel positif kurang dari $10 \%$ & Skor $1:$ Intensitas warna rendah \\
\hline Skor $2:$ Sel positif antara dari $11 \%-50 \%$ & Skor $2:$ Intensitas warna sedang \\
\hline Skor $3:$ Sel positif antara dari $51 \%-80 \%$ & Skor $3:$ Intensitas warna kuat \\
\hline $\begin{array}{l}\text { Skor } 4: \text { Sel positif antara dari lebih dari } \\
80 \%\end{array}$ & \\
\hline
\end{tabular}

1

HASIL

Secara makroskopis terdapat perbedaan antara kelompok kontrol dan yang mendapat PRF. Pada kelompok kontrol, tampak permukaan defek tidak beraturan karena terisi jaringan parut yang lebih tebal sedangkan pada kelompok yang mendapat PRF permukaan defek terlihat lebih teratur dan mulus (gambar 3a dan b). Pada gambar $3 \mathrm{c}$ dan d juga ditunjukkan perbedaan ekspresi imunohistomia antara kelompok kontrol dan perlakuan yang

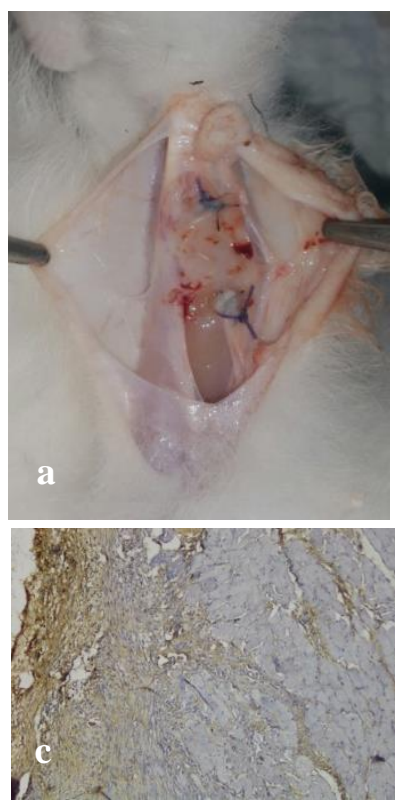

Gambar 3. (a) Gambaran makroskopis defek otot pada kelompok kontrol; (b) Gambaran makroskopis defek otot pada kelompok yang mendapat PRF; (c) Gambaran mikroskopis 
ekspresi Pax7 pada kelompok kontrol; (d) Gambaran mikroskopis ekspresi Pax7 pada kelompok PRF

Tabel 2. Hasil Analisis Skor Ekspresi Pax7

\begin{tabular}{lcccc}
\hline & & Kontrol & PRF & Nilai $\mathrm{p}$ \\
\hline Ekspresi Pax7 & 2 minggu & $4,7 \pm 0,448$ & $5,969 \pm 0,168$ & 0,009 \\
& 4 minggu & $6,32 \pm 0,64$ & $7,97 \pm 0,521$ & 0,017 \\
\hline
\end{tabular}

\section{PEMBAHASAN}

Penyembuhan cedera otot melibatkan peran dari sel punca dan faktor pertumbuhan. Proses penyembuhan dimulai dari proses terbentuknya hematoma atau bekuan darah yang akan mengaktifkan rangkaian proses inflamasi dimana sel-sel proinflamatori untuk regenerasi jaringan akan teraktivasi. Proses ini berlanjut ke proses proliferasi dan diakhiri oleh proses remodeling jaringan otot. Peran sel prekursor adalah pada sel satelit yang terletak di basal lamina otot. Sel ini bersifat inaktif saat tidak terjadi cedera dan menjadi aktif saat terjadi cedera. Sel ini akan berprolifrasi dan memperbanyak diri sebelum kemudian berdiferensiasi menjadi sel mioblas, suatu cikal bakal sel miosit. Selain peran sel prekursor, peran faktor pertumbuhan juga sangat penting. Faktor pertumbuhan yang terkonsentrasi dapat diberikan dalam bentuk PRP atau PRF. Perbedaan kedua kelompok model cedera otot secara makroskopis memberikan penjelasan awal bagaimana pemberian faktor-faktor pertumbuhan dapat memfasilitasi penyembuhan otot. Hal ini sesuai dengan hasil studi yang dikemukakan oleh Wong dan Hamid dimana ketersediaan faktor pertumbuhan yang cukup akan membantu proses penyembuhan yang lebih baik sehingga aktivitas mioblas akan lebih dominan dibandingkan dengan aktivitas fibroblas. Apabila aktivitas myoblas lebih dominan daripada aktivitas fibroblas maka jaringan parut yang terbentuk akan semakin sedikit. ${ }^{1,15}$ Namun pada penelitian ini jaringan parut yang terbentuk hanya dievaluasi secara makroskopis sehingga suatu evaluasi histologis diperlukan untuk memastikan lebih jelas mengenai jaringan parut yang terbentuk tersebut.

Hasil imunohistokimia pada kedua pengamatan Pax7 baik setelah minggu kedua dan keempat menunjukkan bahwa skor yang lebih tinggi didapatkan pada kelompok yang mendapatkan PRF dibandingkan dengan kelompok kontrol. Penelitian yang sudah dipublikasi tentang pemberian efek PRF pada cedera otot masih sangat terbatas. Terdapat satu penelitian di Italia oleh Gigante et al 


\section{Artikel Penelitian}

Vol 7 No. 1, April 2018

ISSN 2460-8742

http://journal.unair.ac.id/ORTHO@journal-orthopaedi-and-traumatology-surabaya-media-104.html

dimana Gigante menggunakan plateletrich fibrin matrix pada model cedera pada otot longisimus dorsi tikus Wirstar. Pada penelitian tersebut, Gigante mengevaluasi secara histologis, dan analisis histomorfometrik. Hasilnya, kelompok yang mendapat matrik PRF menunjukkan neovaskularisasi dan regenerasi yang lebih baik daripada kelompok control. ${ }^{16,17}$ Penelitian lain secara in vitro oleh Viser et al mempelajari kandungan transforming growth factor-beta (TGF- $\beta$ ) pada sel otot yang diberikan PRF. Hasilnya adalah kelompok yang diberikan PRF memberikan nilai kandungan TGF- $\beta$ yang lebih tinggi. Hal ini menunjukkan bahwa pemberian PRF memberikan sumber faktor pertumbuhan yang lebih banyak dalam proses penyembuhan. ${ }^{18}$

Selain karena faktor pertumbuhan yang dikandungnya, PRF juga memberikan keuntungan sebagai scaffold dalam mengisi defek pada cedera. Karakteristik PRF yang berbentuk seperti gel mampu mengisi defek yang terjadi pada cedera otot. Keuntungan scaffold pernah dikemukakan oleh Longo et al yang menyatakan bahwa dengan adanya scaffold pada daerah cedera otot, maka scaffold tersebut akan membantu memfasilitasi pembentukan myotubules baru dimana myotubules yang baru terbentuk akan menjembatani dan pada akhirnya akan mengisi daerah cedera sehingga terbentuk jaringan otot yang baru. ${ }^{19}$

\section{KESIMPULAN}

Pemberian platelet-rich fibrin pada cedera otot dapat dipertimbangkan sebagai pilihan terapi untuk mendapatkan hasil yang baik pada cedera otot dengan defek. Pembuatan platelet-rich fibrin yang relatif mudah nantinya diharapkan dapat diaplikasikan secara klinis pada pasien dengan cedera otot terutama dengan defek yang besar. Hasil penelitian ini dapat dijadikan landasan untuk melakukan penelitian lanjutan dengan menggunakan variabel yang lebih banyak dan aplikasi sel punca. Ke depannya, penggunaan PR yang dikombinasikan dengan sel punca diharapkan dapat memberikan solusi terbaik dalam penanganan cedera otot.

\section{REFERENSI}

1. Wong, S., Ning, A., Lee, C., \& Feeley, B. T. (2015). Return to sport after muscle injury. Current Reviews in Musculoskeletal Medicine, (8), 168-175.

http://doi.org/10.1007/s12178-0159262-2

2. Krushell J. 2004. Sport injuries are on the rise. Available from: 
http://krushperformance.com/sportsinjuries-are-on-the-rise/ Juni 2016

3. Menetrey J, kasemkijwattana C, Dac $\mathrm{CS}$, Bosch $\mathrm{P}$, Vogt $\mathrm{M}, \mathrm{Fu} \mathrm{FH}$, Moreland MS, Huard J. 2000. Growth factors improve muscle healing in vivo. J Bone Joint Surg [Br], 82, 131137.

4. Sato K, Li Y, Foster W, Fukushima K, Badlani N, Adachi N, Usas A. 2003. Improvement of Muscle Healing Through Enhancement of Regeneration and Prevention of Fibrosis. Muscle Nerve, 28, 365-372.

5. Van den Bekerom, Michel P.J. et al. 2012. What Is the Evidence for Rest, Ice, Compression, and Elevation Therapy in the Treatment of Ankle Sprains in Adults Journal of Athletic Training 2012;47(4):435-443 by the National Athletic Trainers' Association, Inc. www.nata.org/journal-of-athletictraining

6. Jarvinen Tero AH, Jarvinen Markku, Kalimo Hannu. 2013. Regeneration of Injured Skeletal Muscle After the Injury. In: Muscles, Lig and tendons Journal 2013; 3 (4): 337-345

7. Hammond JW, Hinton RY, Curl LA, Muriel JM, Lovering RM (2009) Use of autologous platelet-rich plasma to treat muscle strain injuries. Am J Sports Med 37: 1135-1142.

8. Raja V Sunitha, Naidu E Murinatham. 2008. Platelet-rich Fibrin: Evolution of a secondgeneration platelet concentrate. Indian Journal of Dental Research, 2008; 19(1):42-46

9. Bielecki T, Dohan Ehrenfest. 2012. Platelet-rich Plasma and Platelet-rich Fibrin: Surgical adjuvant, preparations for in situ regenerative medicine and tools fr tissue engineering. Current Pharm Biotechnol, 2012; 13(7):112130

10. He L, Lin Y, Hu X, Zhang Y, Wu H. 2009. A Comparative study of paltelet-rich fibrin and platelet-rich plasma on the effect of proliferation and differentiation of rat osteoblasts in vitro. Oral Surg Oral Med Oral Pathol Oral Radiol Endod, 2009; 108(5):70713

11. Nesligul NK, Timucin B. 2015. The Use of Platelet-rich Fibrin (PRF) and PRF-mixed particulated autogenous bone graft in the treatment of bone defect: An experimental and histomorphometrical study. Dent Res $J, 2015 ; 12(5): 418-424$

12. Dedkov EI, Kostrominova TY, Borison AB, Carlson BM. 2003. MyoD and Myogenin protein 
expression in skeletal muscle of senile rats. Cell and tissue research. vol 311 , no 3, pp 401-16

13. Verdijk LB, Gleeson BG, Jonkers RAM, Meijer K, Savelberg HCM, Dendale P. 2009. Skeletal muscle hypertrophy following resistance training is accompanied by a fiber type-specific increase in satellite cell content in elderly man. $J$ Gerontol A Biol Sci Med Sci, vol 61A, no.3, pp.332-9

14. Novak M, Madej JA, Dziegeil P. 2007 Intensity of Cox 2 expression inCell of Soft Tissue Fibrosarcomas in Dog As Related to Grade of Tumor malignation. Bull Vet inst Pulawy 51, 275-279. 2007

15.Hamid M Sharif, Yusof Ashril, Ali M Razil. 2014. Platelet-rich Plasma for Acute Muscle Injury: A systematic review. PLoS, 2014; 9(2):e90538

16. Wright-Carpenter T, Opolon P, Appel HJ, Meijer H, Wehling P, Mir LM. Treatment of muscle injuries by local administration of autologpus conditioned serum: animal experiments using a muscle contusion model. Int J Sports Med. 2004; 25:582-7

17. Gigante A, Del Torto M, Manzotti S, Cianforlini M, Busilacchi A, Davidson PA, Greco F, Mattiloi-
Bemmonte M. Platelet rich fibrin matix effects on skeletal muscle lesions: an experimental study. Journal of Biological Regulators \& Homeostatic Agents, vol 26, no 3, 475-484 (2012)

18. Visser LC, Arnoczky SP, Caballero O, Egerbacher M. Platelet-rich fibrin constructs elute higher concentratios of transforming growth factor beta1 and increase tendon cell proliferation over time when compared to blood clots: a comparative in vitro analysis. Vet Surg 2010;39:811-17

19. Longo UG, Loppini M, Berton A, Spiezia F, Maffuli N, Denaro V. 2012 Review article: Tissue engineered strategies for skeletal muscle injury. Stem cell international; Vol (2012). 